http://kitaibelia.unideb.hu/

ISSN 2064-4507 (Online) • ISSN 1219-9672 (Print)

(C) Department of Botany, University of Debrecen, Hungary

25(1): 27-32.; 2020

DOI: $10.17542 /$ kit.25.27

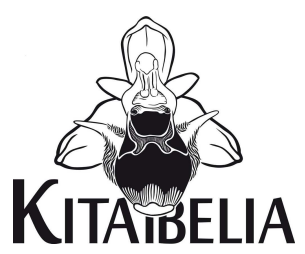

\title{
Az ázsiai gyapjúfü (Eriochloa villosa) elterjedésének vizsgálata Borsod-Abaúj-Zemplén megye északi részén
}

\author{
VIRÓK Viktor*, FARKAS Tünde \& KRAJNYÁK Cecília \\ Aggteleki Nemzeti Park Igazgatóság, H-3758 Jósvafő, Tengerszem oldal 1.; *virokvt@gmail.com
}

\begin{abstract}
Research on the distribution of woolly cup grass (Eriochloa villosa) in the northern part of Borsod-Abaúj-Zemplén county, Hungary
\end{abstract}

\begin{abstract}
Eriochloa villosa (Thunb.) Kunth was recorded for the first time in Hungary in 2007. Since then, the species spread intensively in the area and appeared at some other parts of Hungary. We carried out a research at the current distribution range of the species in the northern part of Borsod-AbaújZemplén county. We asked how big is the infested area surrounding the place of the first occurrence and whether other occurrences could be found in other parts of the investigated area. This article also gives a review on its known localities in Hungary and neighbouring areas. During the field research, 58 locations of the species were identified, it occurred mainly in ploughed and unploughed agricultural fields, and at some places in disturbed grasslands, too. It has spread on a large scale around the neighbouring areas of the first location found in 2007. Other locations were also found even at more distant places such as in the valley of the Sajó and Bódva rivers and in the Cserehát region. This means that further spread of Eriochloa villosa can be expected, especially in areas with an intensive agricultural activity, in disturbed grasslands, and a threat of its appearance is also suspected in open natural habitats.
\end{abstract}

Keywords: arable weed, biological invasion, distribution, invasive species, NE Hungary

Összefoglalás - Az Eriochloa villosa (Thunb.) Kunth első magyarországi adata 2007-ből származik. Az azóta eltelt időszakban a faj intenzíven terjedt, az ország több pontján megjelent. A felmérések során Borsod-Abaúj-Zemplén megye északi részén vizsgáltuk a faj jelenlegi elterjedését. Arra kerestük a választ, hogy első megtelepedésének környékén mekkora területen terjedt el és ettől a területtől elkülönülten, a vizsgált terület más részén is megjelent-e. A közleményben áttekintjük a hazai és az országhatár közeléből származó külföldi adatokat is. A felmérés során 58 lokalitásban találtuk meg a fajt, elsősorban szántóföldeken, parlagokon, de zavart gyepekben is előfordult. Az 2007-ben megtalált lelőhely környezetében nagy területen elterjedt, de attól távolabb is megjelent, így a Sajó- és Bódva-völgyben, illetve a Cserehátban. Az Eriochloa villosa további terjedésére kell számítanunk, különösen az intenzív szántóföldi művelés alatt álló területeken, a zavart nyílt gyepeken, de megjelenése elképzelhető nyílt természetes élőhelyeken is.

Kulcsszavak: biológiai invázió, elterjedés, Északkelet-Magyarország, inváziós faj, szántóföldi gyom

\section{Bevezetés}

Az ázsiai gyapjúfú (Eriochloa villosa (Thunb.) Kunth) kelet-ázsiai eredetű növény, melyet a világ több pontján mezőgazdasági kultúrákat veszélyeztető, gazdasági kárt okozó inváziós fajként tartanak nyilván. Az Európai és Földközi-tenger Melléki Növényvédelmi Szervezet (EPPO) megfigyelési (Observation) listáján szerepel [3]. 
Hazánkban első alkalommal 2007-ben került elő Gesztely határából, ahol Madarász János és Partosfalvi Péter találta (PARTOSFAlvi et al. 2008). Még ebben az évben Dancza István Miskolc belterületén is megtalálta, ahová egy parkoló létesítéséhez hozott termőfölddel került be szintén Gesztely környékéről (Dancza ex verb.). A megkezdett védekezés ellenére a faj ezen a területen tovább terjedt (BALOGH \& NovÁK 2014), de az ország több más pontján is megjelent. Somogyi Noémi és munkatársai (SOMOGYI et al. 2011) jelezték első alkalommal Hajdú-Bihar megyéből, Debrecen mellől. Takács Attila és munkatársai (TAKÁcs et al. 2014) a Dráva-síkon, Szentborbás mellett fedezték fel, majd egy évvel később Pinke Gyula és munkatársai (PINKE et al. 2015) is megtalálták ettől a területtől északra, Tótújfalu és Zádor környékén, mely adatot később közölték is (PINKE et al. 2016a). Szilágyi Arnold és munkatársai (SZILÁGYI et al. 2016a) Debrecentől nyugatra már nagy területen figyelték meg, majd 2019ben (SZILÁGYI et al. 2019) ennek az állománynak további terjedéséről is beszámoltak. 2018ban Koscsó János a gesztelyi előfordulástól északra, Alsódobsza északi határában talált egy állományt (ex verb.). PINKE et al. (2016b) viszont Gesztelytől délre olajtökvetésben figyelték meg a fajt. Fontos tény, hogy a faj Románia nyugati részén, így hazánk keleti országhatára mentén már elterjedt (CIOCÂRLAN \& SIKE 2006, FĂRCĂŞESCU et al. 2007, ARDELEAN et al. 2009, SzATMARI 2016). Más fertőzött határ menti területről nem találtunk adatot. Irodalmi adatok alapján a faj elterjedése hazánkban és a határ menti területeken az 1. ábrán látható.

Széles tűrőképességű fajról van szó, mely a boreális övtől a szubtrópusi területekig előfordul (DARBYSHIRE et al. 2003). Az üde termőhelyeket részesíti előnyben, természetes élőhelyén folyópartokon, vízfolyások mentén húzódó füves élőhelyeken és hegyi réteken él.

A védekezés ellene meglehetősen nehéz, melynek részleteit DARBYSHIRE et al. (2003) foglalják össze, de hazai cikkek is foglalkoznak a témával (PARTOSFALVI et al. 2008, BALOGH \& NovÁK 2014, SZILÁGYI et al. 2016b).

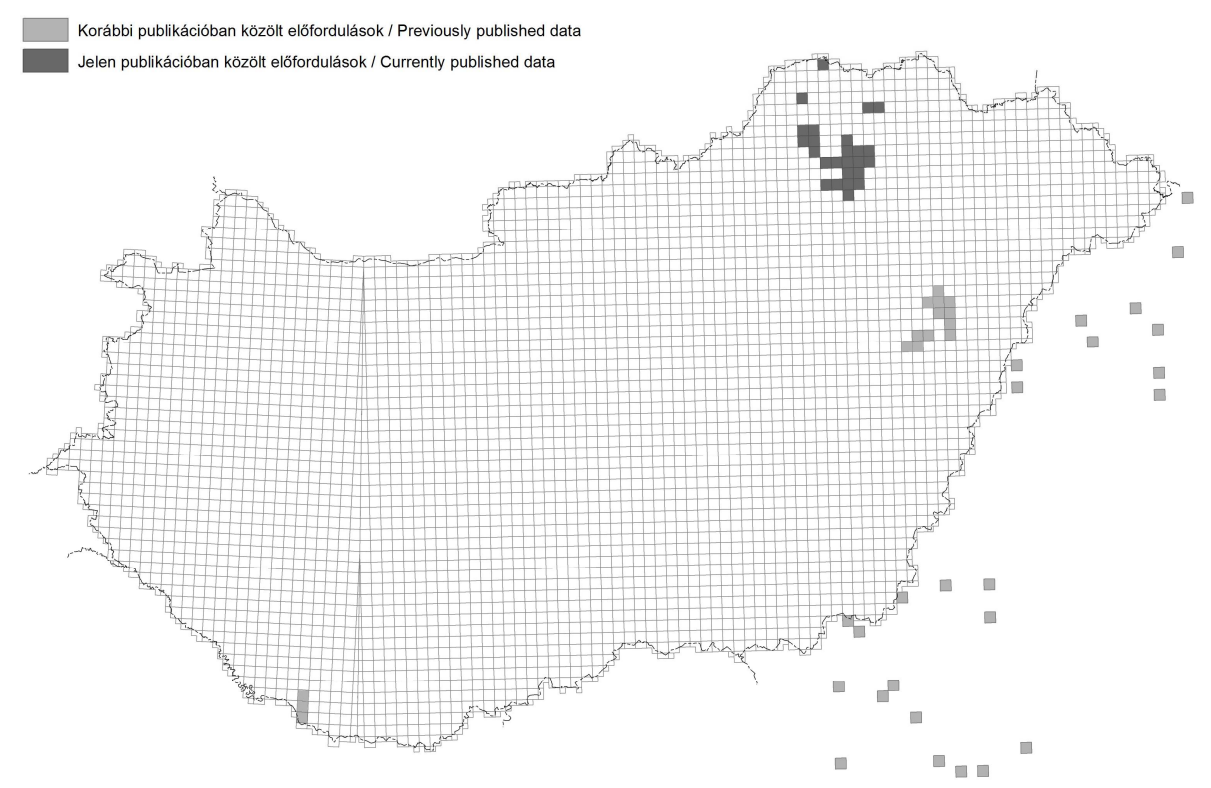

1. ábra Az Eriochloa villosa elterjedése Magyarországon és a határ menti területeken $5 \times 5$ kilométeres UTM hálóban ábrázolva (NEGREAN 2011, TAKÁcs et al. 2014, SZATMARI 2016, SZILÁGYI et al. 2016, 2019 és saját megfigyelések alapján)

Fig. 1 Distribution of Eriochloa villosa in Hungary and in its bordering areas shown in $5 \times 5 \mathrm{~km}$ UTM grids (Based on NEGREAN 2011, TAKÁCS et al. 2014, SZATMARI 2016, SZILÁGYI et al. 2016, 2019 and authors' observations) 


\section{Módszer}

Terepi vizsgálataink Borsod-Abaúj-Zemplén megye északi részét, pontosabban a Sajó, a Tisza és az országhatár által lehatárolt területet érintette. Hazánkban ezen a területen került elő elsőként a faj. Az ellenőrzés az alábbi tájegységekre terjedt ki: Aggtelek-Rudabányaihegyvidék, Tokaj-Zempléni-hegyvidék, Cserehát, Putnoki-dombság, Hernád-, Sajó- és Bódvavölgy, Sajó-Hernád-sík, Harangod és Bodrogköz. A terepbejárások során a faj elmúlt tíz évben bekövetkezett terjedésére voltunk kíváncsiak, és arra, hogy csak a megtalálás helyén terjed szét expanziósan, vagy attól elkülönülten, új területekre is áthelyeződött elterjedése (relokációs terjedés). Annak ellenőrzése is célunk volt, hogy csak szántóterületeken fordul elő, vagy más élőhelyeken is megjelenik. 2018 és 2019 őszén összességében 268 ponton ellenőriztük a faj előfordulását, elsősorban kapás kultúrákban, mezsgyékben, útpadkákon, ruderális termőhelyeken. A bejárások során próbáltunk minél több kapás kultúrát ellenőrizni. Abban az esetben, ha találtunk egy előfordulást, a mintavételek gyakoriságát sűrítettük és ellenőriztük a szomszédos élőhelyeket is. Az ellenőrzött helyszíneket GPS-szel bemértük, és jeleztük, amennyiben előfordult a növény. Külön pontot vettünk fel, ha eltérő élőhelyen fordult elő (pl. szántó és annak a mezsgyéje).

\section{Eredmények}

A felmérés során 58 ponton rögzítettük a faj előfordulását, melyek az alábbi tájegységekben találhatók: Cserehát, Szerencsi-dombság, Sajó-, Hernád- és Bódva-völgy, Sajó-Hernád-sík, Harangod. A gesztelyi előfordulásának környezetében az elmúlt 12 évben $215 \mathrm{~km}^{2}$-es területen terjedt el, Miskolc, Berzék, Tiszalúc, Újharangod, Megyaszó és Szikszó települések által lehatárolt területen. Nagyobb összefüggő elterjedést találtunk a Sajó-völgyben, Sajókeresztúr és Edelény közötti területen. Emellett, pontszerű előfordulásokat találtunk Szalaszend, Szendrő és Hidvégardó települések határában. Három fő gócpontot találtunk, ahol a faj nagy területen és nagy tömegben fordul elő. Az egyik Gesztely és Sóstófalva, a másik Boldva és Sajószentpéter közötti terület, illetve Hernádnémeti mellett Tiszalúc irányában.

Nem csak szántókon, hanem zavart mezsgyékben és zavart, másodlagos nyílt gyepben is megtaláltuk. A termesztett kultúrák közül leggyakrabban kukoricavetésekben, valamivel ritkábban napraforgótáblákban fordult elő. Több helyen tapasztaltuk, hogy amennyiben a vetésforgóban ezeket a kultúrákat repce vagy szója követte, a parcella keskeny szegélyében maradt fenn a faj, a kevésbé intenzív kezelések miatt. Gabonakultúrákból kiszorul, mivel aratáskor még nem érlel termést, a tarlóhántás pedig megakadályozza további fejlődését. Helyenként nagy tömegben találtuk elsőéves parlagokon. Azon táblák mellett, ahol tömegesen előfordult, gyakran megtaláltuk a mezsgyében is (elsősorban Boldva település környékén). Egy alkalommal találkoztunk vele zavart, nyílt gyepben, a Miskolc mellett létesített Sajó árlevezető vápájának partján. A hidvégardói állomány miatt, mely az országhatár mellett található, ellenőriztük az előfordulását Szlovákia határmenti területein. Itt nem találtuk meg, ami feltehetően annak is köszönhető, hogy a mezőgazdasági művelés során jól láthatóan, szigorúan betartják az agrotechnikai előírásokat. Felméréseink alapján a vizsgált területen az ázsiai gyapjúfü elterjedését a 2. ábra mutatja.

Az alábbi KEF alapmezőkből került elő a faj: 7490.2, 7590.3, 7692.2, 7790.1, 7790.2, 7790.3, 7790.4, 7791.4, 7890.2, 7891.1, 7891.2, 7891.3, 7891.4, 7892.1, 7892.2, 7892.3, 7991.1, 7991.2, 7991.4, 7992.1, 7992.3. A termőhelyek az alábbi megoszlásban fordultak elő az egyes alapkőzettípusokon: 69\% folyóvízi üledéken, 22\% löszön, 5\% deluviális üledéken [1]. Talajok szerint a megoszlás az alábbiak szerint alakul: 69\% réti talajok, 7\% barna erdőta- 
lajok, 7\% csernozjom talajok és 2\% öntés talajon [2]. Ez a megoszlás hasonló képet mutat az eredeti élőhelyével, ahol elsősorban folyóvölgyekben, folyók menti réteken, alkalmanként hegyi gyepekben fordul elő. A megtalált állományok esetében a tengerszint feletti magasság 105 és 196 méter között változott.

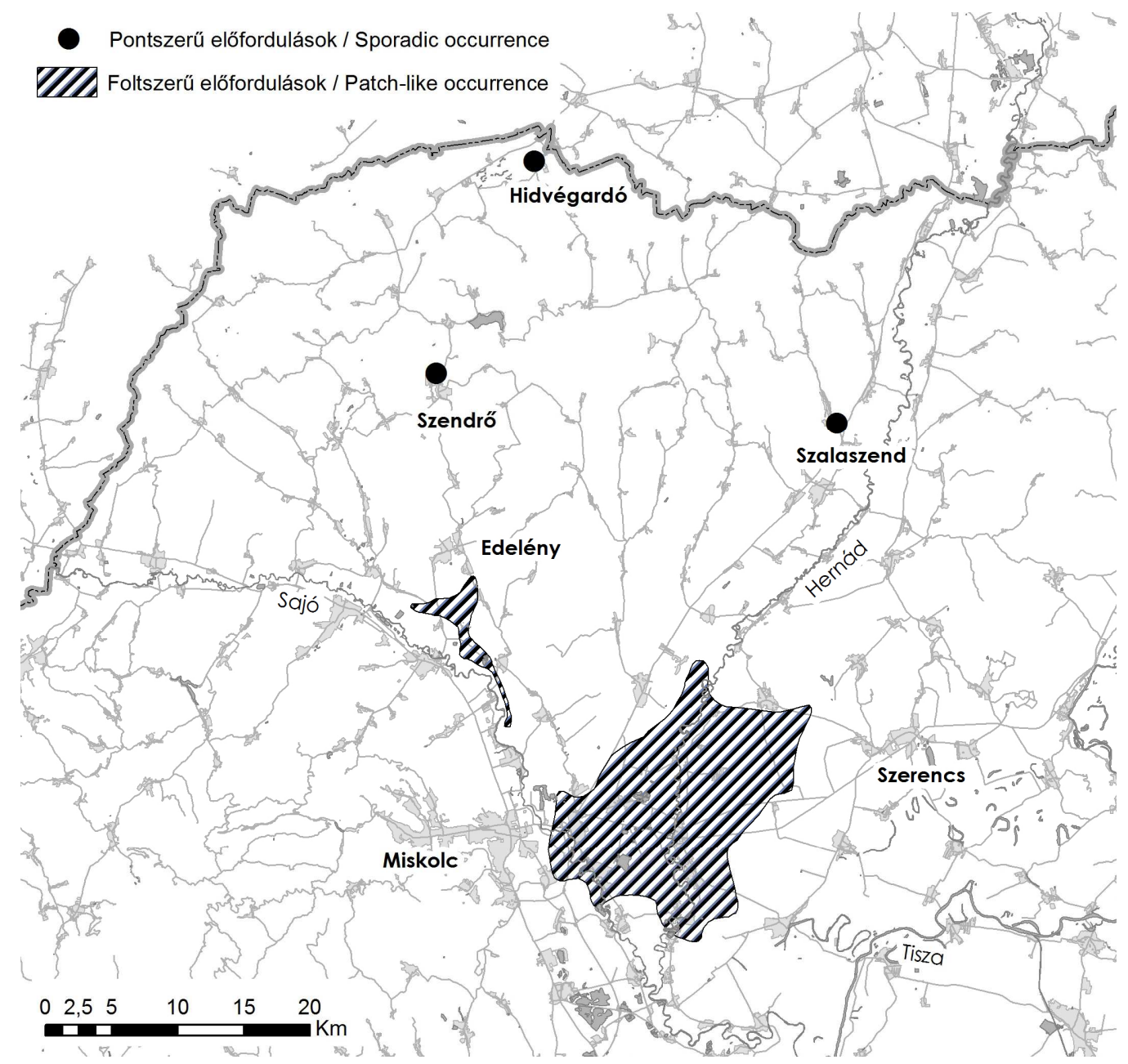

2. ábra Az Eriochloa villosa elterjedése a vizsgált területen

Fig. 2 Distribution of Eriochloa villosa in the investigated area

\section{Következtetések}

A faj nagyon gyors terjedést mutat, ahogy ezt SzATMARI (2016), valamint SzILÁGYI et al. (2019) is kimutatták. Ezt segíti számos tulajdonsága: allelopatikus hatása (SzILÁGYI et al. 2020), jó alkalmazkodó képessége, az önmegporzás képessége, a képződő szemtermések nagy száma, jó ellenálló képessége egyes gyomirtó szerekkel szemben, és jó regenerálódó képessége a kaszálások után. C4-es növényről lévén szó, gyorsabb növekedése, hatékonyabb vízhasznosítása és jobb hőtűrése miatt várhatóan a klímaváltozáshoz is jól fog alkalmazkodni. A szántóföldeken végzett vegyszeres gyomirtást tapasztalataink alapján a zavart mezsgyékben és a parcellák szélén átvészeli, ahonnan könnyen visszafertőzi a táblákat. 
A felmérés alapján jól látható, hogy tíz év alatt a faj expanziós terjedéssel nagy területeket hódított meg. Ugyanakkor relokációs terjedés is megfigyelhető, hisz az eredeti elterjedésétôl távol, pontszerűen jelent meg Szalaszend, Szendrő és Hidvégardó határában. Több korábbi publikáció is megjegyzi, hogy a szemtermés nagy mérete miatt a terjedésben várhatóan mezőgazdasági művelő- és betakarítóeszközök fognak a legnagyobb szerephez jutni. Ez a mód elsősorban a faj expanziós terjedését segíti, míg az újabb lelőhelyek kolonizációjánál elsősorban a fertőzött vetőmaggal történő továbbjutás jöhet szóba, ahogy például Kanadába is bekerült a 2000-es évek elején (DARBYSHIRE et al. 2003). A hidvégardói állomány esetében - mivel a vizsgált területen ez található legmesszebb az eredeti, Gesztely környéki előfordulástól próbáltuk kideríteni, hogy a használt művelőeszközök milyen térségben mozogtak. Az érintett területen ellenőriztük, de csak a korábban elókerült egyetlen állományt találtuk, így feltételezhető, hogy nem a művelőeszközökkel, hanem vetőmaggal került a területre a faj.

A vizsgált területen intenzív terjedését segíthetik az M3-as autópálya építésének Hernádvölgyben folyó munkálatai. Hegy- és dombvidékeken elsősorban az utak mentén, ruderális élőhelyeken lehet számítani gyengébben fejlődő példányaira. Emellett bolygatott talajfelszínen, nyílt természetközeli vegetációban is megjelenhet, ahogy ARDELEAN et al. (2009) is jelzik. SZATMARI (2016) temetőben is találta, ahol szintén szárazabb termőhelyen élt. Ugyanakkor a termések terjedése nagy méretük miatt korlátozott, egyértelműen az emberi tevékenységhez kötött, így várhatóan erős antropogén hatás alatt álló élőhelyeken fog intenzíven terjedni. Fontos felhívni a figyelmet arra, hogy az Agrár-környezetgazdálkodás horizontális és zonális (MTÉT) program szántó előíráscsoportok választható előírásai alapján növényvédőszermentes szegély alakítható ki a bevitt szántó terület legalább 25\%-án, legalább 3 évig, legalább 3 vagy 6 méter szélességben. Ezekben a vegyszermentes szegélyekben a gyapjúfú könnyen fenn tud maradni és terjedni, szaporodni képes. A jövőben érdemes figyelemmel kísérni ezeken a területeken a faj esetleges megtelepedését.

Mivel a faj elterjedt Románia nyugati részén (CIOCÂRLAN \& SIKE 2006, ARDELEAN et al. 2009, FĂRCĂŞESCU et al. 2007, SZATMARI 2016), a faj terjedése várható hazánk keleti, intenzív mezőgazdasági művelés alatt álló részein (Szabolcs-Szatmár, Hajdú-Bihar, Békés és Csongrád megyében).

\section{Köszönetnyilvánítás}

Ezúton szeretnénk megköszönni Pinke Gyula, Dancza István, Koscsó János és Takács Attila hasznos tanácsait, illetve az Aggteleki Nemzeti Park Igazgatóság támogatását.

\section{Irodalom}

Ardelean A., Karacsonyi K. \& Negrean G. (2009): Eriochloa villosa, new alien plant for Arad County (Romania). - Studia Universitatis Vasile Goldiş, Seria Ştiinţele Vieţii 19(2): 281-282.

BALOGH Z. \& NovÁK R. (2014): Adatok az ázsiai gyapjúfü (Eriochloa villosa) Borsod-Abaúj-Zemplén megyei terjedéséhez és az ellene való védekezés lehetőségeihez. - 60. Növényvédelmi Tudományos Napok. Abszraktkötet. Budapest, 2014. február 18-19., p. 79.

CiocÂRlan V. \& SiKe M. (2006): Eriochloa villosa (Thunb.) Kunth (Poaceae) in the Romanian flora. Buletinul Grădinii Botanice Iaşi 13: 105-107.

DarbyshiRE S. J., Wilson C. E. \& Allison K. (2003): The Biology of Invasive Alien Plants in Canada. 1. Eriochloa villosa (Thunb.) Kunth. - Canadian Journal of Plant Science 83: 987-999.

FĂRCĂŞESCU A. M., ARSENE G.-G \& NEACȘU A.-G. (2007): Eriochloa villosa (Thunb.) Kunth: A new species for the banat flora. - Research Journal of Agricultural Science 39(1): 483-488.

Negrean G. (2011): Addenda to "Flora Romaniae" Volumes 1-12. Newly published plants, nomenclature, taxonomy, chorology and commentaries (Part 1). - Kanitzia 18: 89-194. 
Partosfalvi P., Madarász J. \& Dancza I. (2008): Az ázsiai gyapjúfű (Eriochloa villosa (Thunb.) Kunth) megjelenése Magyarországon. - Növényvédelem 44(6): 297-304.

Pinke Gy., Blazsek K., NAgy K., Karácsony P. \& MagyaR L. (2015): Néhány adventív gyomnövény előfordulása Magyarország szójavetéseiben. - XI. Aktuális flóra- és vegetációkutatás a Kárpátmedencében nemzetközi konferencia. Abszraktkötet. Budapest, 2016. február 12-14., p. 213.

Pinke Gy., Blazsek K., Nagy K., Karácsony P. \& Magyar L. (2016a): A magyarországi szójavetések gyomviszonyai. - Növényvédelem 77(52/2): 75-82.

PinKE Gy., KARÁCSONY P., BlAZSEK K. \& NAGY K. (2016b): A magyarországi olajtökvetések gyomviszonyai. Növényvédelem 77(52/12): 589-594.

Somogyi N., SZABó L. \& DÁvid I. (2011): Az ázsiai gyapjúfü (Eriochloa villosa /Thunb./ Kunth) megjelenése Hajdú-Bihar megyében. - Agrártudományi Közlemények, Különszám 43: 119-123.

SZATMARI P-M. (2016): Monitoring invasive woolly cupgrass Eriochloa villosa in the Pir village area, Satu Mare County, Romania, and its impact on segetal flora. - Acta Horti Botanici Bucurestiensis 43: 41-55.

SzILÁGYi A., TóTH T. \& RAdócz L. (2016a): Az ázsiai gyapjúfű (Eriochloa villosa [Thunb.] Kunth) új előfordulása a Hajdúsági kistérség területén. - Agrártudományi Közlemények 71: 51-54.

SZILÁGYI A., RADÓCZ L. \& BALOGH Z. (2016b): Az ázsiai gyapjúfü gyomnövény hazai terjedése. Növényvédelmi melléklet. - Mezőhír 2: 22-24.

SzilÁgYi A., Tóth T. \& RADócz L. (2019): Az ázsiai gyapjúfü (Eriochloa villosa [Thunb.] Kunth) újabb előfordulásai a Hajdúsági kistérség területén. - Georgikon for agriculture, Különszám 23(1): 70-75.

SZILÁGYI A., NAGY A. \& RADócZ L. (2020): Ázsiai gyapjúfü (Eriochloa villosa [Thunb.] Kunth) hajtás- és gyökérkivonatok allelopatikus hatásának vizsgálata fehér mustár (Sinapis alba L.) csírázási teszttel. - Georgikon for agriculture, Különszám 24(1): 75-82.

TAKÁCS A., NAGY T. \& MolnáR V. A. (2014): Három szórványos előfordulású, behurcolt pázsitfüfaj [Dasypyrum villosum (L.) Borbás, Eleusine indica (L.) Gaertn. és Eriochloa villosa (Thunb.) Kunth] új adatai a Dél-Dunántúlról. Apró közlemények. - Kitaibelia 19(1): 176.

\section{Világháló oldal}

[1] MBFSZ térképszerver https://map.mbfsz.gov.hu/

[2] Magyarország genetikus talajtérképe https://www.uni-miskolc.hu/ ecodobos/ktmcd1/terkep.htm

[3] EPPO Földközi-tenger Melléki Növényvédelmi Szervezet (EPPO) vészjelzési (Alert) és megfigyelési (Observation) listái https://www.eppo.int/ACTIVITIES/plant_quarantine/alert_list

Beérkezett / received: 2020. 02.18. • Elfogadva / accepted: 2020. 03. 31. 